\title{
CSPP-L and EB3 localize to centriolar satellites and are required for satellite-dependent recruitment of ciliopathy proteins to the centrosome
}

\author{
J Sternemalm¹, S Geimer ${ }^{2}$, EK Aarnes ${ }^{1}$, KM Frikstad ${ }^{1}$, T Stokke ${ }^{1}$, LB Pedersen ${ }^{3}$, S Patzke ${ }^{1 *}$ \\ From Cilia 2014 - Second International Conference \\ Paris, France. 18-21 November 2014
}

\section{Objective}

Centrosome/Spindle Pole associated Protein 1 (CSPP1, JBTS21) mutations cause Joubert syndrome (JBTS) and JBTS-related ciliopathies. The large protein isoform CSPP-L is a ciliary protein required for ciliogenesis and stabilization of the ciliopathy protein RPGRIP1L (NPHP8/JBTS7/MKS5/FTM) at the ciliary transition zone (TZ). However, RPGRIP1L is dispensable for ciliogenesis and the mechanism by which CSPP-L promotes ciliogenesis is unclear.

\section{Methods}

We applied immunogold electron, immunofluorescence and fluorescence live cell microscopy to determine localization of CSPP-L at high spatial and temporal resolution. We elucidated the functional interplay of CSPP-L with centriolar satellites in hTERT-RPE1 and HeLa cells using biochemical analysis of CSPP-L complexes, siRNA modulated gene expression and quantitative immunofluoresecence microscopy.

\section{Results}

We show that CSPP-L localizes to centriolar satellites, in addition to axonemal microtubule (MT) plus ends and the $\mathrm{TZ}$, and that the MT plus end-tracking protein EB3 also localizes to satellites. CSPP-L complexed with the known satellite component PCM1 and GFP-CSPP-L showed satellite-like dynamics. Importantly, CSPP-L depletion decreased formation of PCM1, CEP290 and EB3-comprising satellites, whereas depletion or inactivation of EB3 impaired centrosomal localization of CSPP-L.

'Institute for Cancer Research, Dept Radiation Biology, OUH - Norwegian Radium Hospital, Oslo, Norway

Full list of author information is available at the end of the article

\section{Conclusion}

Our results identify a new link between MT plus ends and centriolar satellites, and suggest that CSPP-L contributes to ciliogenesis by promoting EB3- and dynein-dependent recruitment of satellite components to the centrosome.

\section{Authors' details \\ 'Institute for Cancer Research, Dept Radiation Biology, OUH - Norwegian Radium Hospital, Oslo, Norway. ${ }^{2}$ Cell Biology / Electron Microscopy, University of Bayreuth, Bayreuth, Germany. ${ }^{3}$ Department of Biology, University of Copenhagen, Copenhagen, Denmark.}

Published: 13 July 2015

doi:10.1186/2046-2530-4-S1-P76

Cite this article as: Sternemalm et al:: CSPP-L and EB3 localize to centriolar satellites and are required for satellite-dependent recruitment of ciliopathy proteins to the centrosome. Cilia 2015 4(Suppl 1):P76.
Submit your next manuscript to BioMed Central and take full advantage of:

- Convenient online submission

- Thorough peer review

- No space constraints or color figure charges

- Immediate publication on acceptance

- Inclusion in PubMed, CAS, Scopus and Google Scholar

- Research which is freely available for redistribution

Submit your manuscript at www.biomedcentral.com/submit
( Biomed Central 